\title{
Marketing Communication Strategy of Online Shop to take advantage of Instagram Application (Case Study on Online Shop@cutrizkyhijab1)
}

\author{
Laila Rohani', M.Yoserizal Saragih' ${ }^{2}$, Anang Anas Azhar ${ }^{3}$, Anita Wulanie Fitri ${ }^{4}$ \\ 1,2,3,4 Universitas Islam Negeri Sumatera Utara, Indonesia \\ wulaniefitri@gmail.com
}

\begin{abstract}
This study aims to find out online shop marketing communications@cutrizkyhijabl on instagram and to find out the advantages and disadvantages of online shop@cutrizkyhijablon marketing through Instagram media.The theory used in this study is the theory of social media, Instagram, marketing communication, and the Marketing Mix. The subjects of this research are Owners and 10 permanent consumers cutrizkyhijabl listen research time from April to August. The method used in this research is the Qualitative Method with Indepth Interview (in-depth interview). Technical analysis used is descriptive qualitative analysis. The results of this study indicate that the marketing communication strategy carried out through Instagram media is used by online shop owner @cutrizkyhijablthrough promotions on the Instagram application. Of the various supporting features on Instagram, the features that are most often used are the Instagram photo upload feature and Story Highlights. The advantages of online shop@cutrizkyhijablCompared to other online shops, it lies in conveying messages to consumers by using the features available on Instagram, prices and up to date products for each product variation.Disadvantages of online shop@cutrizkyhijab1 in the form of competition between other online shops, thus making the owner@cutrizkyhijabl must be diligent to post photos or videos so that their products can be seen by consumers.
\end{abstract}

Keywords marketing; communication strategy; online shop

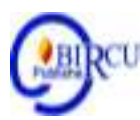

\section{Introduction}

The development of information technology is rapidly evolving. Various small to large business activities utilize this development to run their business. The number of competitors is a consideration for entrepreneurs to enter into very tight competition. The right marketing and media strategy is used to be able to reach the intended market so that sales volume is always increasing and profit. Digital Marketing is one of the marketing media that is currently in demand by the public to support various activities carried out. They are little by little starting to abandon the convesional/traditional marketing model of switching to modern digital marketing. (Gunawan, G. et al. 2020)

This information moves very quickly, because of the creation of information and communication technology. Therefore, it is very easy for humans to carry out communication activities. In today's digital era, social media is no stranger to hearing. Social media is one of the media used to communicate or socialize online without any 
Konfrontasi Journal: Culture, Economy and Social Changes, 8 (3) September 2021, 218-228

ISSN: 1410-881X (Print), 2716-2095 (Online)

Laila Rohani, M.Yoserizal Saragih, Anang Anas Azhar, Anita Wulanie Fitri: Marketing Communication Strategy of Online Shop to take advantage of Instagram Application (Case Study on Online Shop @cutrizkyhijab1)

DOI: $h$ ttps://doi.org/10.33258/konfrontasi2.v8i3.159

http://www.konfrontasi.net/index.php/konfrontasi2

limitations of space and time. One of the social media that is currently growing rapidly is Instagram.

Instagram is a photo or video sharing application that allows users to take photos, take videos, apply digital filters and share them on various social networking services, including Instagram's own. Instagram can be used by all walks of life and that's what makes Instagram lately on the rise. The initial purpose of the creation of Instagram was to be able to communicate remotely by anyone but as we know now Instagram is starting to develop with various features in it, we can get information both scientific information and events that are viral, and Instagram is also one of the most popular social media. used to wrestle the business world for hookers in the business world,

Instagram provides features that make it easier for business people to attract consumers by building a good image by uploading product photos to make it more attractive and attractive.business people must have a good interaction relationship between sellers and buyers so that the image that has been built so far is not damaged, one way is through the features on Instagram, namely insta-stories, business people can show product photos or videos so that buyers believe that the goods we sell are true and don't forget to give testimonials, or through friends which was originally from mouth to mouth or word of mouth while showing his Instagram account. it could also be with a detailed product introduction to make it easier for consumers to choose goods. There have been many businessmen who have started to spread their wings in the world of the Instagram platform, but the more opportunities there are, the more risks. Entrepreneurs are required to be innovative and creative so as not to be left behind by other entrepreneurs. This is where marketing communication comes in. where every businessman is required to have their own strategy in managing their business in order to get feedback from consumers. Instagram has become a medium used for online business means or what we often hear as Online Shop.

An online shop is a place where there is a sale of goods or services on the Internet, where the seller and the buyer do not meet face to face but through media such as Twitter, Instagram, Facebook and so on. The payment method used by the online shop is in the form of a transfer through the bank account in question, if the payment process has been carried out then the online shop owner is obliged to immediately send the goods to the consumer.

Online media currently has a strategic role in promoting. Although promotion through social media is free, you still have to use a communication strategy for the right promotion. When someone posts a message online, especially in time

If it is not right, it will get simultaneous and fast attention. If the sending of the message gets a lot of likes or "love" and comments immediately after posting, this is a sign to the Instagram account owner that it is quality content and should be shown to more people. However, it really depends on how to develop an account management strategy (Rini, Atwar. 2019).

@ Cutrizkyhijab1is an online shop that uses Instagram as a means to promote their products. This online shop started a career in online business at the end of 2016 by providing a wide range of Muslim women's clothes, bags, shoes, hijabs, which are comfortable at very affordable prices. The promotions carried out are very intense, therefore they continue to maintain a good image so that over time 3 years@cutrizkyhijab1he has a lot of fans and now he has 64.7k followers on Instagram. He applied various marketing communication strategies to achieve satisfactory results, but sometimes@cutrizkyhijab1also received complaints but because they had prepared fast 
and responsive customer service the problem was quickly resolved. With the many advantages of shopping at@cutrizkyhijab1 there are also some drawbacks such as an irregular ordering schedule and also the production of clothes that are not much but the demand is very much so that consumers often do not get the clothes they want he wanted.

The promotions were very intense, therefore they continued to maintain a good image so that over time 3 years@ cutrizkyhijab1he has a lot of fans and now he has $64.7 \mathrm{k}$ followers on Instagram. He applied various marketing communication strategies to achieve satisfactory results, but sometimes@cutrizkyhijablalso received complaints but because they had prepared fast and responsive customer service the problem was quickly resolved. With the many advantages of shopping at@cutrizkyhijab1 there are also some drawbacks such as an irregular ordering schedule and also the production of clothes that are not much but the demand is very much so that consumers often do not get the clothes they want he wanted.

Marketing communication is a communication activity carried out by buyers and sellers which is very helpful in making decisions in the field of marketing, as well as directing exchanges to be more satisfying by making all parties aware to do better. Marketing communication is a marketing activity that seeks to disseminate information, influence/persuade, and remind the target market of the company and its products to be willing to accept, buy, and be loyal to the products offered by the company concerned.1 Advantages of using Instagram as a tool marketing communication is that every online shop owner can increase sales widely and does not require too expensive marketing costs.

The purpose of marketing communication has three stages, namely: changes in knowledge, changes in attitudes and changes in the behavior of a consumer in this case the author is interested in describing in depth marketing communications in the form of a promotion mix that is carried out.@cutrizkyhijab1 in promoting products by utilizing the Instagram application as an online communication medium.

Therefore, to find out the promotion strategy carried out,@cutrizkyhijab1 then the author conducted a research "Online Shop Marketing Communication Strategy in Utilizing the Instagram Application (Case Study on Online Shop @cutrizkyhijab1)"

\section{Review of Literature}

\subsection{Social Media}

Social media in the real world is connecting with people or colleagues, friends, and using that media to meet new people. In cyberspace, the principle is the same, but the power of technology provides another advantage, namely users are no longer obstructed by place and space. Users can view people's profiles and send e-mails anytime and from any computer. In fact, sometimes, communicating through cyberspace feels more comfortable and complete than communicating face to face. Overall adults tend to use social media for personal reasons and not work.

Social media is one of the products of the emergence of new media. In social media, individuals and groups interact with each other online through the internet network. Since its emergence, the media is not only used by individuals but also by organizations or companies large and small to communicate with the public. Social media is used by utilizing technology in communicating. The technology referred to here is the Internet. It is open and anyone can access it. (Khairifa, F. et al. 2019) 


\subsection{Instagram}

Instagram is an image-based social media that provides online photo or video sharing services. Instagram comes from the understanding of the overall function of this application. The word "insta" comes from the word "instant", like the polaroid camera which at that time was better known as "instant photo". Instagram can also display photos instantly, like a polaroid in its display. As for the word "gram" comes from the word "telegram" which works to send information to others quickly. Similarly, Instagram can upload photos using the Internet, so the information you want to convey can be received quickly. That's why Instagram is an extension of the words instant and telegram. On the Instagram app, allows users to upload photos and videos into a feed which can be edited with various filters and organized with tags and location information. Uploads can be shared publicly or with pre-approved followers. Users can browse other users' content by tags and location and view trending content. Users can like photos and follow other users to add their content to the homepage.

\subsection{Marketing Communication}

Marketing communications emerged as a more complex and different form of communication. In the end, many academics and practitioners define marketing communication as all the promotional elements of the marketing mix or other terms of the marketing mix that involve communication between organizations and target audiences.

Marketing communication is a means by which companies try to inform, persuade, and remind consumers directly or indirectly about the products or brands they sell. The explanation above can be concluded that marketing communication is a two-way exchange of information between parties or institutions involved in marketing communications marketing.2As for the opinion of experts about marketing communication. According to Sutisna, marketing communication is an effort to convey messages to the public, especially target consumers, regarding the existence of products in the market. 3

\section{Research Methods}

The research approach used in this study is a qualitative approach. Because the qualitative approach is a research procedure that produces descriptive data in the form of written or spoken words of people and observable behavior. The qualitative approach has natural characteristics as a direct, descriptive data source, the process is more important than the result. Analysis in qualitative research tends to be done by inductive analysis and meaning is essential. Therefore data collection relies on interviews with the Owner/Owner@cutrizkyhijab1

\section{Result and Discussion}

Search part of a marketing and communication has its own role in the preparation of marketing communications strategy. In the process of improving online shop marketing@cutrizkyhijab1seek various strategies that can support these efforts, one of which is through social media. As we know, the development of the internet era has entered various aspects of life as well as the world of marketing armed with smart phones, virtual market activities are open twenty-four hours, seven days a week to provide almost everyone's needs. 
Online business systems are easier to do and do not require large investments both at the start and when operating. It only requires a good internet connection as initial capital to build an online business. The nature of the online market which is very dynamic and demands rapid changes, requires appropriate reactions and steps so that a product or service can survive and win the competition.

Fork answer the analysis of the formulation of the first and second research questions related to online shop marketing communication strategies @ cutrizkyhijab1 moma The researcher conducted interviews with parties directly related to the research as well as additional data in the form of documentation that could assist the author in the research. Additional data referred to in this study are interview transcripts and pictures or research locations.

This research is done in this thesis is in the form of qualitative descriptive, namely research by presenting data in qualitative form to objects based on the facts and facts that appear on the object. Therefore, this research is descriptive qualitative in that the data obtained from interviews with informants are described thoroughly. Interview data in research is the main data source that becomes data analysis material to answer research problems.

Related with the title of this research, namely the online shop marketing communication strategy in utilizing the case study instagram application on the online shop@ @utrizkyhijab1, the researcher will try to present the data obtained from the results of research in the field. The resource person in this study is the owner@cutrizkyhijab1 and 10 consumers from @ cutrizkyhijab1.

\subsection{Marketing done@cutrizkyhijab1}

Strategy online shop marketing@cutrizkyhijab1the first to prioritize the pleasure of Allah SWT, focus on how to find blessings in work and talk modestly with customers, there is no such thing as manipulation of their product offerings. Online shop @ cutrizkyhijab1 focus to the products sold and following the trends are also keeping up with the times, consumers will automatically of the times. Here, when the products being sold are of higher quality and the products subscribe. In marketing, the marketing strategy carried out by the online shop@cutrizkyhijab1 by the 4P concept. Marketing communication activities require the existence of a marketing concept. Kotler believes that the marketing concept has 4 functions, namely the 4Ps, including product, price, location and promotion. 


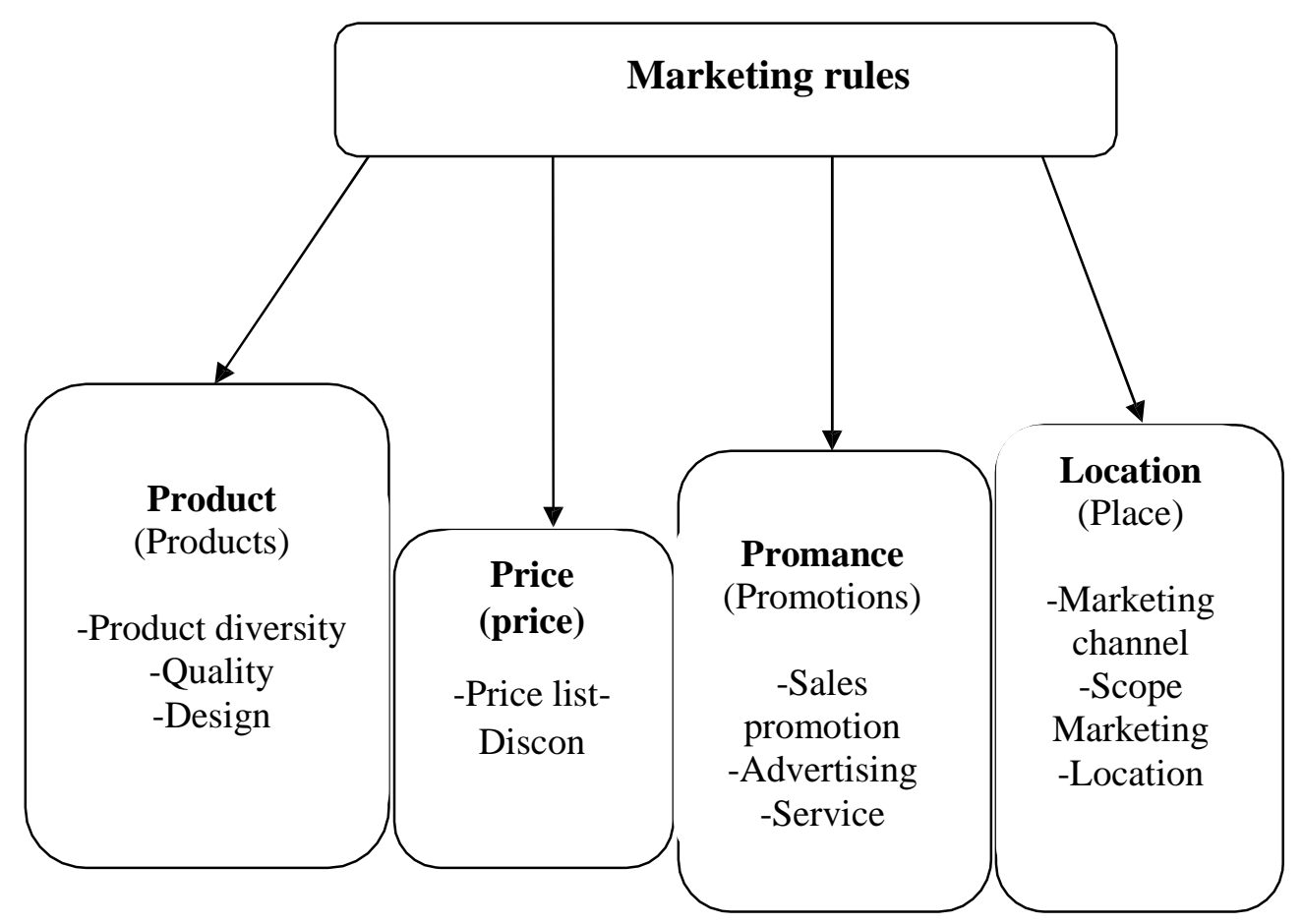

Figure 1. Consensusp Marketing mix 4P

\section{a. Product}

According to Philip Kotler, many people think the product is a real offer, but the product can be more than that. Broadly speaking, a product is anything that can be offered to a market to satisfy a want or need, including physical goods, services, experiences, events, people, places, property, organizations, information and ideas. Product offerings are the first step in shaping a marketing mix strategy. online shop@cutrizkyhijab1,offering products that consumers need and seek every day. The products that are traded also have their own characteristics. According to Umi cut as the owner of the online shop @ cutrizkyhijab1, products marketed by cutrizkyhijab, products that are currently trendy with several brands.

"We sell here, which have their own characteristics, so here there are approximately 10 well-known brands and these are the products that are trending now. It is in the form of headscarves, robes, tunics, caftans, and mukenahs. Alhamdulillah so far it turns out that many people like it. There are also products that can be obtained from their own products, some are from suppliers"

From the owner's statement above, it can be concluded that the products being marketed follow the trend / era with the selection of products that are not marketed so that many consumers glance at the products offered by online shops.@cutrizkyhijab1. So by selling products that are being sought after by consumers, many consumers and potential consumers come and buy products according to their needs. 


\section{b. Price}

The price is determined in the name of the currency that the consumer must pay when buying a product or exchanging product ownership rights. Prices include final prices, discounts or rebates, and retail prices. Pricing and price competition are considered as the main problems faced by companies, because pricing strategies are very important in providing value to consumers, as well as influencing product image and consumer purchasing decisions. In marketing their products, Umi cut sets a standard price but the quality of the product is good. The goal is to attract the attention of consumers to be interested in buying their products.

"if in our online shop, the price for the product is worth it, for example, we sell hijab for 250-400 and the cloth from the hijab is very good, the cloth is soft, easy to shape, not hot, the material is thick, sometimes there is a veil that is see-through, this is not. So we sell good products at the right price."

This is also felt by a consumer named Bela Aldana, she said that the products offered are in accordance with the prices set by the company@cutrizkyhijab1, anyways in @ cutrizkyhijab the products are already well-known brands.

From the results of the exposure of the owner and one of the consumers, it can be concluded that the prices they offer are in accordance with the products being marketed so that consumers are not disappointed when buying products.

\section{c. Promotion}

Promotion is a type of communication that gives convincing explanations to potential consumers about goods and services. The purpose of promotion is to get attention, remind and convince potential customers. This includes sales promotion, advertising, service, public relations, direct marketing:

1. Sales promotion, Promotion is a core element of marketing activities consisting of a series of incentive tools, mainly short term, aimed at stimulating consumers or trade to buy certain products or services sooner or later. Its purpose is to accelerate sales and gather marketing information.

"for our own promotions, we usually have certain times using giveaways, discounts on each product with so many consumers coming and buying discounted products. How to inform that there is a discount here, we usually upload it on instastory. With so many consumers, umi knows that cutrizkyhijabl is having a big sale and a discount."

This is also felt by one of the regular consumers @ cutizkyhijab1 Nanda Azura who said often getting giveaway and discounts on some product items@ @utrizkyhijab1.

It can be concluded that sales promotions carried out online shop@cutrizkyhijab1, mego through giveaway activities regularly, and discount All items. That way consumers will be interested and come to buy.

2. Advertising, is any paid form of non-personal presentation and promotion of ideas, goods or services by an identified sponsor. The ability of advertising to influence the target audience to think and behave in certain ways is still a question. Flexibility in advertising is considered good because it can be used to communicate widely to the target audience even though the costs incurred are also very high. Introducing or promoting an online shop@cutrizkyhijab1 This is the first step to attracting potential 
customers. @ cutrizkyhijab1 also has a strategy in promoting the products that are sold. With the advancement of the times and today's electronics, @cutrizkyhijab1 take advantage of advertising through social media Instagram.

"Usually for advertising, sometimes I use local celebgrams like Cutbul, sometimes I ask for help from friends who have a lot of followers, the rest I often upload and instastory on the ig feed@cutrizkyhijabl. That way, Alhamdulillah, many potential consumers are interested."

From the statement above, it can be concluded that online shop @ cutrizkyhijab1 only using advertisements through Instagram social media by means of endorsements and also posting themselves, with endorsements able to attract many potential consumers from various circles.

3. Peservice, @ cutrizkyhijab1Provide courteous, courteous and friendly service to customers. So that when the service is good, the buyer will be happy and then be able to buy the existing product.

This is felt by Pertiwi, as one of the consumers of @ cutrizkyhijab1, yang says "in terms of service I admit the owner@cutrizkyhijab1friendly sOnce, we don't get tired of shopping with him, he's a funny person, and the problem of bargaining is good with him, likewise his employees are leaking. Anyway, it's comfortable shopping where he is" It can be concluded that, the services provided by@cutrizkyhijab1 can make consumers comfortable when shopping there.

4. Public Relations, Public relations is a comprehensive communication effort from a company to influence perceptions, opinions, beliefs and attitudes of various groups towards the company. Public relations include various programs to promote or protect the image or individual products of the company, (Philip Kotler, 2008: p. 229). The increase in public relations users is a reflection of a form of communication that has high credibility. There are many forms and methods used by public relations, including lobbying, managementn events, sponsorship12. According to umi cut as Owner mensaid that so far, in establishing relationships with consumers, they usually prioritize fast responses from the admin. So the consumer also feels comfortable communicating with our admin.

5. Direct advice, is the use of consumer direct channels to reach and deliver goods and services to customers without the use of marketing intermediaries.

"For direct marketing I use two ways, the first one is using social media Instagram, the second is using the shop that I opened. For Instagram, I promote items by uploading existing items and new items besides Instagram stories to provide information to followers@cutrizkyhijablthat there is something new. For stores, I usually also instastory the state of the store every day. Usually I will inform you about the condition of the store three to four times a day. Alhamdulillah, every day there must be a lot of people who come to the shop."

From the statement above, it can be concluded that online shop @ cutrizkyhijab1direct marketing through Instagram and stores. By utilizing the instastory feature on Instagram, it can attract the attention of potential consumers with a large number of followers reaching 647 thousand. 


\section{d. Location}

Place is generally understood as a location, a useful and beneficial space for sellers to provide convenience for consumers to reach out to obtain products, so the place or location must be strategic to make the products produced or sold affordable and available in the market including marketing channels, market coverage. , location grouping, transportation inventory. Shop okasi@cutrizkyhijablincluding those close to the crowd strategically located in the city of lhokseumawe on Jl. Darussalam No.34, Kp Jawa Baru, Banda Sakti, Lhokseumawe City, Aceh. So it is very easy to find the cutrizkyhijab address because it is in the middle of the city. And even then, one of the marketing targets carried out by Umi Cut is choosing a strategic location.

"From the start, I chose a strategic place so that it was easy for people to reach, so that we too can target the market with that strategic location, because with strategic placement, many people know our place."

It can be concluded from the statement above that the owner chooses a strategic place so that it can be easily reached by potential consumers.

\subsection{Weaknesses and Advantages@cutrizkyhijab1}

a. Weaknesses of Online Shop@ cutrizkyhijab1

Starting an online business starts with filling needs and building credibility, but there are factors that make online businesses hugely successful, not just stopping here because of the large amount of competition between other online businessmen.

Online shop@cutrizkyhijab1 have quite a lot of competitors around lhokseumawe in terms of marketing and sales, the more sellers of Muslim clothing, making @ cutrizkyhijab1more creative in terms of marketing and selling their products. About what will be traded.@cutrizkyhijab1 divingbut it's positive that there are new online shops that have sprung up, with other online shops ready to enter market, @ cutrizkyhijab1 more motivated to be able to compete with the new online shop. With the quality of goods that are maintained and the goods that are traded are not marketed, it makes@cutrizkyhijab1 still retain their customers. The good quality of the products being traded so that consumers prefer certain things, rather than having to go to other places, but the quality of the goods being traded is not clear.

\section{b. Advantages of Online Shop@ cutrizkyhijab1}

Social media now has an important role in the marketing strategy of small and large businesses, now sharing information with visitors or followers is not the only advantage of using social media for a business, increasing the types of social media that are increasingly varied, ranging from personal social media, blogs even eComerce also supports the development of the business trip.

In using Instagram as a promotion,@cutrizkyhijab1has the advantage of conveying the seller's message to consumers, where each photo post can be seen by potential consumers who follow the cutrizkyhijab1 Instagram account. The message conveyed is that there are various product variations, prices for cutrizkyhijab1 products are affordable compared to other online shops. This can be seen from the number of consumers who buy products in online shops @ cutrizkyhijab1.

"In my opinion, Instagram's superiority is in its features, all features can actually be used as promotions, because each feature can make it easier to convey messages to consumers, but I often use the Instagram photo and video 
upload feature, highlight. Only by using it, I was able to find consumers and attract consumers to be interested in my product. Besides that, there are a lot of cutrizkyhijabl followers, so I take advantage of the number of followers too. So every product that I offer can be seen by my followers. And nowadays many also use the Instagram application to sell. In addition to promoting features, I also play with prices where the price of the product must match the product offered. So consumers are not disappointed but are more interested in my product than anywhere else."

In taking advantage of the advantages of online business, @cutrizkyhijab1 puts forward affordable prices among consumers, who are the majority of the upper class but @ cutrizkyhijab1can adjust the price to be affordable by all people. As said by voulina who is a consumer of@cutrizkyhijab

"The advantage of the online shop cutrizkyhijabl in terms of price is that they sell products at prices that match good quality, besides that the goods sold are up to date they always inform you of new products through instastory and vary."

Other than that a convenient store also makes@cutrizkyhijab1get a distinct impression from consumers. This is also explained by Natasya, one of the consumers

"I think the place is comfortable, then the variety of goods is different from other places. Then the cashier's service, the saleswoman, and even the owner are very friendly, sometimes they like to joke. The items sold are fashionable and reliable.

From the explanation above, it can be concluded that the advantages that exist in the online shop are:@cutrizkyhijab1 lies in conveying messages to consumers about the products being marketed and affordable prices and the variety of products offered. This is what makes consumers interested in online shops@ cutrizkyhijab1.

\section{Conclusion}

Based on the results of the research described above, the following conclusions can be drawn:

Marketing communication strategy carried out through Instagram media used by online shop owners@ cutrizkyhijab1through promotions on the Instagram application. Of the various supporting features on Instagram, the features that are most often used are the Instagram photo upload feature and Story Highlights. In the instastory feature, umi cut uses it to inform the latest product and store situation every day. As for uploading photos, Umi Cut uses it to post new products with attractive layouts. Highlights Stories are used to provide important information such as how to order online, store location instructions, and more. The features used are considered very effective and helpful in the product promotion process@cutrizkyhijab1,because it can convey messages directly to consumers. By utilizing the number of followers that reached 647 thousand, it made it easier for Umi Cut to promote products.

The advantages of online shop@cutrizkyhijab1Compared to other online shops, it lies in conveying messages to consumers by using the features available on Instagram, prices and up to date products for each product variation. With prices that match the 
product than other online shops, it makes consumers come and buy products at @ cutrizkyhijab1, meeven though the difference from other online shops is a little.

Disadvantages of online shop@cutrizkyhijab1 bethe form of competition between other online shops to make owner@cutrizkyhijab1 you have to be diligent in posting photos or videos so that the product can be seen by consumers, if not then@cutrizkyhijab1will be in danger of losing customers. People will switch to other online shops that are better than@cutrizkyhijab1.

\section{References}

Alyusi, S. D. (2016). Media Sosial: Interaksi, Identifikasi, dan Modal Sosial. Jakarta: Kencana Cangara, Hafied. Pengantar Ilmu Komunikasi, Jakarta: PT Raja Grafindo Persada, 2011.

Efendy, onong Uchyana. (2004). Ilmu Komunikasi Teori dan Praktek. Bandung: PT Remaja Rosdakarya Offset.

Gunawan, G. et al. (2020). Determining Factors in the Use of Digital Marketing and Its Effect on Marketing Performance in the Creative Industries in Tasikmalaya. Budapest International Research and Critics Institute-Journal (BIRCI-Journal). P. 2543-2550.

Hermawan, Agus. (2012). Komunikasi Pemasaran. Jakarta: Erlangga

Khairifa, F. et al. (2019). The Relationship of Social Media Usage to the Satisfaction and Practice of Friendship (Silaturahmi) among Students of Universitas Sumatera Utara. Budapest International Research and Critics Institute-Journal (BIRCI-Journal). P. 575-589.

Kotler, P and Gary A. (2013). Prinsip-prinsip Pemasaran, (Terjemahan Ancella Anitawati Hermawan), Jilid I Edisi 13, Prehallindo, Jakarta.

Kotler, P. (2013). Manajemen Pemasaran, Analisis Perencanaan dan Pengendalian, (Terjemahan Ancella Anitawati Hermawan), Jilid II, Edisi 13, Prehallindo, Jakarta.

Morissan . (2010). Periklanan :Komunikasi Pemasaran Terpadu.Jakarta: Kencana Prenada Media Group

Meoleong, Lexy J.(2010). Metode Penelitian Kualitatif. Bandung: PT Remaja Rosdakarya Offset.

Soegiyono, (2013). Metode Penelitian Kuantitatif, Kualitatif dan R \& D, Bandung: Alfabeta.

Tjiptono, Fandy. (2014). Pemasaran Jasa - Prinsip, Penerapan, dan Penelitian, Andi Offset, Yogyakarta.

Watie, E. D. S. (2011). Komunikasi dan media sosial (communications and social media ). The Messenger, 3(1), 69-75. 